\title{
PRINCIPAL FACTORS DEFINING SUCCESS OF TECHNICAL-TACTICAL ACTIONS OF ELITE FOOTBALL TEAM
}

\author{
Yerlan Adambekov \\ Kazakh National Pedagogical University Named after Abay, Almaty, Kazakhstan
}

\begin{abstract}
Research background and hypothesis. Factor analysis method enables to reveal the complex of dominating indicators determining the competitive result, as well as to define extend of interrelation between indicators and establish the role of individual factors important in the achievement of sports result.

The aim of this study was to reveal manifestations of factors of technical-tactical actions determining success of football teams taking part in the country's championship.

Research methods. The study participants were 24 football players from elite level "Aktobe" team, playing in Kazakhstan Premier League and the champion of Kazakhstan. The technical-tactical actions was analysed separately and compared during the first and the second rounds of the championship (11 games in each round).

Research results. The analysis of factor contribution into the structure of technical-tactical actions in the first and the second rounds of the country's championship showed that during the second round of the championship the volume of technical-tactical actions, indicating the possession of play initiative, decreased from 49.6 to $44.1 \%$ of total variance, but the contribution of technical-tactical actions, indicating completing of team's attacking actions, increased from 16.5 up to $24.8 \%$ of total variance. It enabled the team to score more goals in the second round of the championship.

Discussion and conclusions. Pursuant to the factor analysis, such indicators as "short and medium passes forward", "long passes", "interceptions", "hitting the goals" and "total number of technical-tactical actions" are dominating parts of the integral factor - "Possession of play initiative". Quantifying all the activities of individuals, group of players and of the entire team, which contributed to achievement of elite football teams, is essential in programming and managing the training process.
\end{abstract}

Keywords: football, game analysis, technical and tactical preparation.

\section{INTRODUCTION}

$\mathrm{T}$ The structure of highly qualified athletes' training process is based on objectively existing rules having specific peculiarities for different sports (Платонов, 2004). The value of the data related to the game analysis can serve as feedback information for coaches when planning and programming training activities as to prepare for competitive performance of individuals or the team in football (Janković, Leontijević, 2008; Lago, 2009; Lago et al., 2010).

In K. Adambekov's (Адамбеков, 2007) and S. Tiulenkov's (Тюленьков, 2007) opinion, competition activity in sports games is characterized by vast variety, complexity and resourcefulness, but success depends on numerous factors and different aspects of athlete's preparation. The analysis of separate correlation coefficients does not provide complete understanding of the leading factors, defining control of football players' technicaltactical preparation at each training stage and, what is most important, of their quantitative significance in it. At the stage of the analysis of different sources, it is not possible to reply with certainty to the main question of the work considering the significance of 
diagnostic indicators in their complex interaction, which can provide different results (Ali, 1988; Reilly et al., 2000).

Rational planning of a long-term training process is in many respects related to the exact definition of the structure of competition activity and athlete's preparation, which provide for successful sports results (Годик, 2009) as well as to defining of main factors limiting the results in different sports and establishing inter-dependence between these factors (Franks, McGarry, 1996).

Lately, specialists in various sports apply vastly the factor analysis method, which enables to reveal the complex of dominating indicators, determining the sports result, as well as to define the extend of interrelation between indicators and establish the role of individual factors affecting the sports result (Маслов, 2002; McGarry, 2005; Bjelica, 2008; Taylor et al., 2010). Thus, the essence of factor analysis is in distinguishing several main factors among a large number of interrelated indicators, which play the role of more fundamental variables, as they characterize the phenomenon (Carling et al., 2005). The factors themselves are important causes of the established correlations between the indicators. That is why the aim of the analysis was to define the factors on the basis of the study of correlation coefficients between different parameters and their correct interpretation (Reilly, Korkusuz, 2009).

In accordance with the algorithm of the main components method, reliability of the research results was achieved setting the condition that the rate of the selection of components with significant correlations between them was not less than $60 \%$ of total variance.

This circumstance enables us to select the main indicators among many others and accordingly correct the training program for athletes. This is particularly important when preparing elite football players, as the arsenal of technical preparation for them should be wide enough (Chartad, Cotte, 2011; Шамардин, 2012; Gražulis, Kareiva, 2013).

The aim of this study was to reveal the factors of technical-tactical actions of hifgh-performance football team during the country's championship.

The aim of this study was to reveal manifestations the factors of technical-tactical actions determining success of football teams taking part in a country's championship.

\section{RESEARCH METHODS}

The participants of this study were 24 football players from high-performance "Aktobe" team, taking part in Kazakhstan Premier League and the champion of Kazakhstan. The assessment and analysis of the results obtained during the study was divided in two parts, i.e. during the first round of the country's championship and during the second round of the championship. At each round the team played 11 games with Premier League teams of the country. The total of 22 games was taken for the analysis.

The following indicators of technical-tactical actions were registered during each game: 1) short and medium passes forward; 2) short and medium passes backwards; 3) headings; 4) long passes; 5) ball control; 6) dribbling; 7) ball interception; 8) winning the ball; 9) hitting the goals; 10) the total number of technical-tactical actions.

The method of mathematical statistics was used for the calculation of arithmetical mean values (X), their standard deviation (S) and the error of average values (Xs). Correlation analysis of the received data was performed using the method of Pearson's rectilinear dependence.

For the detection of the complex of dominating indicators during the game, as well as for the evaluation of the influence of each of them for sports results, the factor analysis of the data was carried out. Three factors F1, F2, F3 were distinguished from the data matrix according to their significance. The indicators of F1 included the actions demonstrating the possession of play initiative; F2 - completing the team's attacking actions; F3 - winning the ball for the development of the attacking actions of the team. Contribution of each factor was normalized, i. e. evaluated in percentage from the total variance.

\section{RESEARCH RESULTS}

The results obtained during the study are presented in Tables 1 and 2 and Figure 1. Figures in tables marked bold were significant correlations and in our study were assessed as strong correlations.

The results of the performed factor analysis of technical-tactical preparation of football players during the first round of the championship are presented in Table 1, in which the structure of indicators is defined by three factors and the total 
selection variance is $79.9 \%$. The first and the most significant factor with a high factor loading which contributed to the total variance of $49.6 \%$, consisted of 5 indicators: short and medium passes forward, long passes, ball interception, hitting the goals and the total number of technical-tactical actions. This factor was named as "possession of play initiative".

The second factor with the total contribution into the selection variance of $16.5 \%$ with the highest factor loading included the indicator of hitting the goals $(\mathrm{r}=-0.819)$. Medium loading in the second factor was characteristic of short and medium passes across and backwards, and ball control $(\mathrm{r}=0.557$ and 0.561 accordingly). This factor was named as "completing the team's attacking actions".

The third factor accounted for $13.8 \%$ of total selection variance and the highest loading was laid upon winning of the ball $(\mathrm{r}=-0.707)$, short and medium passes across and backwards $(\mathrm{r}=-0.553)$, and dribbling $(\mathrm{r}=0.543)$ was characterised by a medium loading. The above mentioned factors enable us to consider them as creating conditions for winning of the ball in order to develop the team's attacking actions.

As the result of the performed factor analysis of technical-tactical actions in the second round of the championship, three factors were also selected with their contribution into the total selection variance of $81.6 \%$ (Table 2).

The first and the most significant factor included the indicators of short and medium passes forward, long passes, interception, hitting the goals, which accounted for $44.1 \%$ of the total number of technical-tactical actions with factor loadings from $\mathrm{r}=-0.769$ to -0.917 .

The second factor (24.8\%) included short and medium passes across and backwards $(r=-0.802)$,

\begin{tabular}{|c|c|c|c|c|}
\hline \multirow{2}{*}{ No. } & \multirow{2}{*}{ Indicators } & \multicolumn{3}{|c|}{ Factors } \\
\hline & & F1 & F2 & $\mathbf{F 3}$ \\
\hline 1 & Short and medium passes forward & -0.915 & 0.016 & 0.204 \\
\hline 2 & Short and medium passes across and backwards & -0.487 & 0.557 & -0.553 \\
\hline 3 & Long passes & -0.816 & 0.206 & 0.185 \\
\hline 4 & Headings & -0.474 & -0.298 & -0.336 \\
\hline 5 & Ball control & -0.575 & 0.661 & 0.189 \\
\hline 6 & Dribbling & -0.343 & -0.117 & 0.543 \\
\hline 7 & Ball interception & -0.882 & -0.117 & 0.208 \\
\hline 8 & Winning of the ball & -0.452 & 0.068 & -0.707 \\
\hline 9 & Hitting the goals & -0.860 & -0.819 & -0.056 \\
\hline 10 & Total number of technical-tactical actions & -0.987 & 0.097 & 0.057 \\
\hline & Total contribution into selection variance, $\%$ & 49.6 & 16.5 & 13.8 \\
\hline
\end{tabular}

\begin{tabular}{|c|l|c|c|c|}
\hline \multirow{2}{*}{ No. } & \multirow{2}{*}{ Indicators } & \multicolumn{3}{c|}{ Factors } \\
\cline { 3 - 5 } & & F1 & F2 & F3 \\
\hline 1 & Short and medium passes forward & $\mathbf{- 0 . 7 6 9}$ & -0.514 & 0.082 \\
\hline 2 & Short and medium passes across and backwards & 0.270 & $-\mathbf{0 . 8 0 2}$ & -0.079 \\
\hline 3 & Long passes & $\mathbf{- 0 . 8 0 4}$ & -0.411 & -0.016 \\
\hline 4 & Headings & -0.483 & 0.096 & 0.012 \\
\hline 5 & Ball control & 0.419 & $-\mathbf{0 . 7 5 3}$ & 0.246 \\
\hline 6 & Dribbling & 0.625 & -0.469 & 0.254 \\
\hline 7 & Ball interception & $\mathbf{- 0 . 8 6 3}$ & -0.043 & -0.300 \\
\hline 8 & Winning of the ball & -0.152 & 0.141 & $\mathbf{0 . 9 4 3}$ \\
\hline 9 & Hitting the goals & $\mathbf{- 0 . 9 1 7}$ & 0.551 & 0.369 \\
\hline 10 & Total number of technical-tactical actions & $\mathbf{- 0 . 8 2 5}$ & -0.529 & 0.140 \\
\hline & Total contribution into selection variance, $\%$ & 44.1 & 24.8 & 12.7 \\
\hline
\end{tabular}

Table 2. Factor structure of technical-tactical actions during the second round of country's championship 


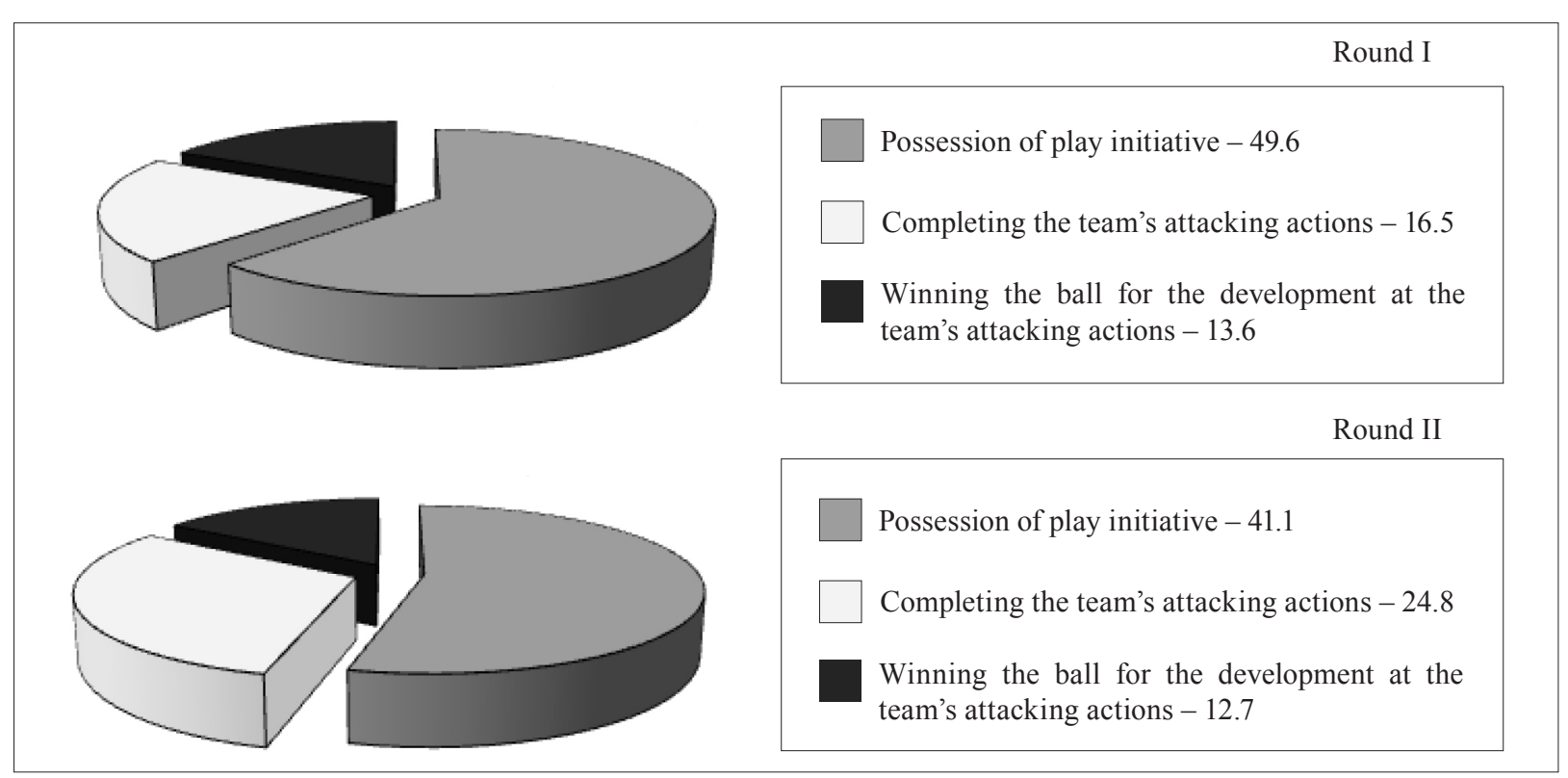

Figure. Important indices of competitive performance

ball control ( $r=-0.753)$, hitting the goals $(r=0.551)$ and the total number of technical-tactical actions $(\mathrm{r}=-0.529)$. The third factor $(12.7 \%)$ factor loading was higher than other indicators of the selection, which was shown only by the "winning of the ball" indicator $(\mathrm{r}=0.943)$.

Figure presents the important indices of competitive performance during the first and the second rounds of the championship. The results obtained during such analysis showed a significant increase $(p<0.05)$ of completing of the team's attacking actions during the second round of the championship. Factor analysis showed that during the second round of the championship the volume of technical-tactical actions, indicating possession of play initiative, decreased from 49.6 to $44.1 \%$ of total variance, but the contribution of technicaltactical actions, indicating the completion of the team's attacking actions, increased from 16.5 up to $24.8 \%$ of total variance. It enabled the team to score more goals in the second round of the championship.

\section{DISCUSSION}

This paper focused attention on the observation of successfully organized attacks which resulted in tactical resource of shot on goal, as well as characteristics of the game with the application of passes, ball possession and the structure of passes. For the purposes of this paper, we analysed the data which directly affected the result of the game as well as the attacking activities of the participating teams. According to the authors quoted herein, one of the selection methods for discriminator signs of technical-tactical preparation indicators is the definition of leading game actions, providing for success of each player in particular and the team in general (Bangsbo et al., 2006; Taylor et al., 2010).

Pursuant to the factor analysis (presented in Tables 1 and 2), such indicators as "short and medium passes forward", "long passes", "interceptions", "hitting the goals" and "total number of technicaltactical actions" are dominating in the formation of the integral factor - "Possession of play initiative". Analogical data were received in the studies of others (Janković, Leontijević, 2008; Lago, 2009; Cărăbas, 2013).

Variation of values of "short and medium passes across and backwards" and "ball control" indicators is explained by the fact that technicaltactical means of the game, in case the team possesses the play initiative, are not significant and their influence is stipulated by the peculiarities of annual training cycle structure (Milanovič et al., 2011).

The value of the third factor (F3) - winning the ball for the development of the team's attacking actions in both stages of the research varied insignificantly (Figure). Factor loading of "winning the ball" in the first stage was $r=0.707$, in the second stage $r=0.943$. It is worth mentioning that more high correlations were registered in the second round of the championship. Thus, there were 7 high correlations in the first micro-cycle, and 8 - in the second one. Consequently, we 
suggest that the dynamics of correlations and their integration into factors defining the game were quite stable during the competition season, and this circumstance was one of the components for the team's successful performance in the country's championship, enabling it to participate in the tournaments of UEFA Cup.

The study of the characteristics of correlations between the components of technical-tactical preparation structure and the selection of the most significant factors in the data matrix defining success in the game enabled to improve football players' preparation and correct the training process, which became the basis of technicaltactical preparation in the annual training cycle of high-performance football teams players.

Modern football requires players with high percentage of correct passes, especially in the manoeuvring space and under the pressure of the opponents (Janković, Leontijević, 2008; Lago, 2009; Lago et al., 2010). Cooperation among players and the efficacy of attacking tactics of the team represents essential information of the playing efficiency in the field. The value of the data related to the game analysis, regardless of their significance, can serve as feedback information for coaches. Such information is useful when planning and programming training activities, but not as the only source of information of competitive performance of individuals or the team in football.

\section{CONCLUSIONS}

1. In the second round of the country's championship the level of the indicators of "possession of play initiative" technical-tactical actions decreased, but at the same time the contribution of the indicators of "completing the team's attacking actions" increased and this circumstance contributed to more effectiveness of attacking actions - to more scored goals.

2. Quantifying all the activities of individuals, group of players and the entire team, which contributed to the achievement of elite football teams, is essential in programming and managing the training process.

\section{REFERENCES}

Ali, A. (1988). A statistical analysis of tactical movement patterns in soccer. In T. Reilly, A. Lees, K. Davids, W. J. Murphy (Eds.), Science and Football. London: E. \& F. Spon. P. 302-308.

Bangsbo, J., Mohr, M., Krustrup, P. (2006). Physical and metabolic demands of training and match - play in the elite football player. Journal of Sports Science, 24 (7), 665-674.

Bjelica, D. (2008). Influence of coordination and psychological factor on the kick precision in football. Acta Kinesiologica, 2 (1), 81-84.

Cărăbas, I. (2013). Aspects regarding the role and the importance of physical preparation in the modern football game. Timisoara Physical Education and Rehabilitation Journal, 5 (10), 61-65.

Carling, Ch., Williams, A., Reilly, T. (2005). Handbook of Soccer Match Analysis: A Systematic Approach to Improving Performance. London and New-York: Routledge.

Chatard, J. C., Cotte, T. (2011). Isokinetic strength and sprint times in English Premier League football players. Biology of Sport, 28 (2), 89-94

Franks, I., McGarry, T. (1996). The science of match analysis. In T. Reilly (Ed.), Science and Soccer. London. P. 363-375.

Gražulis, D., Kareiva, S. (2013). The effectiveness of playing performance of young Lithuanian soccer players. Sport Science, 1 (71), 48-54.
Janković, A., Leontijević, B. (2008). Structure of technical-competitive activity in modern football. Fizička kultura, 62 (1-2), 159-179.

Lago, C., Lago, J., Dellal, A., Gomez, M. (2010). Gamerelated statistics that discriminated winning, drawing and losing teams from the Spanish soccer league. Journal of Sports Science and Medicine, 9 (2), 288-293.

Lago, C. (2009). The influence of match location, quality of opposition, and match status on possession strategies in professional association football. Journal of Sports Sciences, 27 (13), 1463-1469.

McGarry, T. (2005). Soccer as a dynamical system: Some theoretical considerations. In Science and Football. London: Routledge. P. 570-579.

Milanović, Z., Trajković, N., Barišić, V. et al. (2011). Discriminant analysis of soccer tactical elements in the phases of attack and defence determined by cluster analysis. Homo Sporticus, 13 (1), 12-20.

Reilly, T., Korkusuz, F. (2009). Science and football. In The Proceedings of the Sixth World Congress on Science and Football. London: Routledge. P. 494.

Reilly, T., Williams, A., Nevill, A., Franks, A. (2000). A multidisciplinary approach to talent identification in soccer. Journal of Sport Sciences, 18 (9), 695-702.

Taylor J., Mellaliau S., James N., Barter P. (2010). Simulation variable effects and topical performance in professional football. International Journal of Performance Analysis in Sport, 10 (3), 255-257. 
Адамбеков, К. И. (2007). Теория и методика футбола: учебник. Алмата: Елнур.

Годик, М. А. (2009). Физическая подготовка футболистов. Москва: Человек.

Маслов, В. Н. (2002). Исследование факторной структуры специальной работоспособности высококвалифицированных волейболистов. Педагогіка, психологія та медико-біологічні проблеми фізичного виховання і спорту, 21, 88-92.
Платонов, В. Н. (2004). Система подготовки спортсменов в олимпийском спорте. Киев: Олимпийская Литература.

Тюленьков, С. Ю. (2007). Теоретико-методические подходы к системе управления подготовкой футболистов высокой квалификации. Москва: Физическая культура.

Шамардин, В.Н. (2012). Технология подготовки футбольной команды высшей квалификации. Днепропетровск: Инновация.

Corresponding author Yerlan Adambekov

Kazakh National Pedagogical University Named after Abay Spartak Stadium, Omarova str., Almaty

Kazachstan

$\mathrm{Tel}+7$ (727) 3822699

E-mail techcentre.kz@mail.ru 